\title{
Questioning the Rhetoric of Social Mix: Courteous Community or Hidden Hostility?
}

K.J. RUMING, K.J. MEE and P.M .M드는, University of Newcastle.

\begin{abstract}
This paper explores the increasingly important role of 'social mix' in the management practices of the NSW Department of Housing. Social mix is a policy response to the many perceived social, cultural and economic problems concentrated within larger public housing estates. Social mix involves the integration and assimilation of public housing tenants into areas dominated by private home ownership and private rental. Such policies are based upon the belief that social mix has the ability to alter many of these problems simply through the presence of a 'community'. However, this paper questions the normative construction of homeowners as possessing 'community' which by implication will be passed on to public tenants. Through an in-depth casestudy it is shown that 'community', as constructed by social mix policy rhetoric, may in fact further disadvantage public tenants through processes of othering, stigmatisation and oppression, which operate outside traditional understandings of community. In addition, this research shows that rather than increased community integration, it is the physical function of neighbourhood and its direct role in service provision which is the most advantageous constituent of social mix.
\end{abstract}

KEY WORDS: social mix; public housing; community; neighbourhood; oppression; social exclusion.

\section{Introduction}

Social mix and mixed tenancy areas are increasingly positioned as the new ideal for the development of public housing (Gallard, 1999); however, research on mixed tenancy areas, both in Australia and overseas, has been limited (however, see Arthurson, 2002; Atkinson \& Kintrea, 2000; Peel, 1995; Foster, 1997; Galster \& Zobel, 1998), with the majority of research still based on large-scale public housing estates. This paper aims to identify social mix as an ideological policy instrument 
embedded within normative notions of community. Despite such community ideologies, areas of social mix still actively promote stigmatisation, oppression and exclusion. Policies of social mix in effect move processes of oppression and exclusion to a smaller, less obvious scale, giving an impression of success. This study will add to the limited literature concerning the impact of policies of social mix on the lives of residents, both public and private, while evaluating the normative beliefs which dominate policy thinking.

The paper begins by exploring the notions of community and neighbourhood which play a vital role in the ideological underpinnings of social mix, by exploring the normative construction of community which dominates theoretical literature and policy development. It will also consider the increasing body of literature concerned with community and the oppression of difference. In addition, it will also investigate the literature on neighbourhood, focussing especially on its physical role of service provision. The second section briefly explores housing policy developments over past decades which have influenced the construction of public housing. The following two sections explore the empiric of this research (Belmont) and the methodologies used. The fifth section examines the perceptions of housing managers in the Belmont region. This is followed by discussions of community development and association in Belmont, the process of othering and oppression experienced by public housing tenants, and the role of neighbourhood in the provision of services. The conclusion questions the success of policies of social mix and explores the role played by scale. In addition to critiquing the success of social mix, this paper highlights the importance of neighbourhood and its vital role in the provision of services. 


\section{Notions of community and neighbourhood}

Community is one of the most commonly used phrases in the social sciences; however, despite its high level of usage, the variety of meanings subscribed to community is potentially limitless, determined principally by when and in what circumstances 'community' is used, as well as by and for whom (Jewkes \& Murcott, 1998). The notion of community is an abstract concept, containing several dimensions, and involving different sets of experiences for different groups of people, and indeed for some people at different times of their lives. However, despite difficulties in establishing clear and concise definitions, community is habitually constructed by academics, government bodies and the wider society as a positive and constructive entity (Williams, 1976).

\section{Community as an ideology}

Community has come to represent the ideals of the 'good life', an all encompassing whole which is positioned as inherently good, and towards which we should actively strive (Wild, 1981; Plant, 1974; also see Massey, 1991; Young, 1990a;). The ideology of community revolves around notions of rootedness, cohesion and belonging, representing a society free from oppression and domination (Young, 1990a). Many researchers have suggested that community provides mutual support and understanding in times of joint hardships and social disadvantage (Richards, 1990; Forrest \& Kearns, 1999; Peel, 1995).

Figure 1 highlights the normative assumptions which dominate community literature. Ideological constructions of community contain two separate but equally important factors: security and support. First, security provides residents with a safe 
environment which is constructed as their own, and second, support allows for the construction of social relationships and interactions among people who are constructed as similar and equal. Community has masqueraded as the spokesperson of the common idealised good, an invisible social construct in which all people have the same beliefs, strive for the same goals, and work collectively to achieve results beneficial to that community often at the expense of individual wants and desires (Studdent, 1999; Sexton, 1995).

\begin{tabular}{|c|c|}
\hline Small-scale & Common values \\
Local & Common experiences \\
Togetherness & Common culture \\
Belonging & Working towards common goals \\
Cohesion & Symmetry \\
Mutually sympathetic & \\
Security & (Mutual) Support \\
\hline
\end{tabular}

Figure 1 - Normative assumptions of community.

Theoretical notions of community have centred on four main areas of thought: community as geography; community as locally based relations; community as relationship irrespective of location; and community without propinquity. These are briefly explored below.

First, community has often been defined as geography or territory; that is, a finite and bounded location (Wild, 1981; Altman \& Wandersman, 1987). This perspective argues that all the required features for community (and thus a full and 
happy life) are found within a spatially defined area. Secondly, community can be seen as a local system, that is a locality-based system of interrelated social institutions and relationships (Wild, 1981; Silk, 1999). These perspectives on community, and their relationship to a small-scale local place have a strong link to the increasingly important body of literature related to the function and purpose of the neighbourhood, as will be seen in following section. The third perspective positions community as a particular kind of human relationship or association irrespective of location where there is an association and connection among people, despite never having met. (Wild, 1981). Such a notion is very similar to Anderson's (1991) 'imagined communities'. The final perspective is 'community without propinquity', which relates to people's ever increasing association and connections with the wider society and the resultant decrease in attachment to small local communities and places (Rivlin, 1987, Amin and Thrift, 2002).

Although normative associations and ideologies dominate community literature many researchers have questioned the nature of community as an inherent good, or all encompassing entity. Researchers such as Young (1990a, 1990b), Dwyer (1999), Jacobs \& Fincher (1998), and Peel (1995), have argued that the most serious consequence of the desire for community is that it often operates to exclude or oppress those perceived as different. In mixed tenancy areas, the notion of community as potentially oppressive is vitally important.

\section{Community and the oppression of difference}

Traditional concepts of community revolved around notions of sameness and togetherness. However, Young (1990b) has suggested that "the ideal of community denies, devalues, or represses the ontological difference of subjects, and seeks to 
dissolve social inexhaustibility into the comfort of a self-enclosed whole” (p.230). The implication of this is that not all people are the same and that difference should be incorporated into theories of community. The list of potential differences ignored by traditional theories of community is substantial, including gender, age, race, sexuality and disability; however, in this paper the primary axes of difference examined are household tenure and income.

Jacobs \& Fincher (1998) argue that regimes of difference lead to oppression and exclusion of some groups marked as other. Oppression of the other constrains individuals’ autonomy and freedom to choose a way of life, leaves little room for criticism and change, and may sustain structural hierarchies facilitating class exploitation (Smith, 1999). The identification of 'us' and 'them' in a particular place at a particular time is often the result of the uneven material conditions of daily life (Peel, 1995; Cresswell, 1996; Rodriguez, 1998).

Public housing tenants are some of the most socially and economically disadvantaged social groups in contemporary society. Ironically, places of social mix are therefore potentially places of social exclusion through community. The construction of the 'us' and the 'them' allows for the definition and reinforcement of group identities, which form the basis of oppression and exclusion, whilst simultaneously constructing homogeneous entities that ignore internal structures and differences (Duncan, 1993).

\section{Neighbourhood}

While the concept of neighbourhood is becoming an increasingly important theoretical notion in the social sciences, there is no single, generalisable interpretation (Kearns \& Parkinson, 2001). Neighbourhood has traditionally been viewed from an 
ecological perspective, highlighting the importance of geographical, physical and symbolic boundaries. More recent attempts at definition have attempted to integrate social and institutional organisation and relationships at a neighbourhood level (see Galster, 2001 for an brief overview of exact definitions). The neighbourhood is considered a known place, the arena of predictability, relaxation, attachment, belonging, and as a purveyor of status. Kearns and Parkinson (2001) argue the neighbourhood is significant because it is "an important component of the competitive social and economic world; a reservoir of resources into which we can 'dip' in pursuing our lives; an influence upon our lifestyles and life-outcomes; a 'shaper' of who we are, both as defined by ourselves and by others” (p. 2109). Thus, the concept of neighbourhood attempts to bring the social and physical together in order to reconcile the myriad of institutions, organisations and physical environments which characterise daily life.

Like community, neighbourhood is a scaled process. According to Kearns and Parkinson (2001) there are three main scales of neighbourhood: Home area; Locality; and Urban District or Region. The functions of neighbourhood are wide and varied: they provide psycho-social benefits (through providing home space and community); they provide a setting for residential activities (including access to services); they provide social status and position (through the operation of the housing market) and they provide landscapes of social and economic opportunities (through employment connections, leisure interests and social networks) (Kearns \& Parkinson, 2001). The neighbourhood can be seen as a series of overlapping networks (Atkinson \& Kintrea, 2001). It is possible that residents are members of a number of simultaneous scaled neighbourhoods, based on place of residence, employment opportunities, recreational 
activities, etc. The neighbourhood is thus a possible source of both opportunity and constraint.

For the purpose of this research, neighbourhood is seen to represent the physical functions of place, that is service provision, access to transport, commercial facilities, leisure, etc. This is done in an attempt to highlight the physical, service goals incorporated into notions of social mix. As far as policies of social mix are concerned, the multitude of social relations vital to life are brought together under the idiom of community. Neighbourhood itself is not included in the social mix rhetoric, however; it provides a social analytical tool which enables the importance of services and location to be analysed.

\section{Housing policy changes, public housing and social mix}

The general goal of Australian housing policy is to ensure all Australians have access to adequate shelter (Yates \& Vipond, 1991). Since the 1920s Australian governments (state and federal) have engaged in the direct provision of public housing. However, attitudes towards and support for public housing has changed considerably since it was first developed (Paris, 1993; Bisset et al, 1994). As a result, housing policy is increasingly implicated in the development of a system of binary opposites which positions ownership as the natural and correct tenure, and public housing as abnormal and hence inferior.

Housing policy change and the normalisation of ownership

The most significant development in Australian housing policy was the implementation of the Commonwealth-State Housing Agreement (CSHA) in 1945, which actively promoted public housing (Kemeny, 1981). However, in subsequent 
CSHAs, this support has been severely curtained. Under the Menzies Government CSHA of 1956, much of the support for public housing was redirected into private ownership (Kemeny, 1983). As a result, a significant amount of public housing development occurred through the construction of large-scale public housing estates. Examples of housing developments established under such policies in NSW include Mount Druitt and Green Valley in Western Sydney, and Windale and Booragul in the Lake Macquarie area, south of Newcastle. Currently, public housing estates account for about 30\% of Australia’s total social housing stock. Since 1978 there has been a significant shift away from state funded public housing provision to the provision of rent assistance through the federal Department of Social Security, a process which accelerated in the 1990s (Caufield, 2000; Yates \& Wulff, 2000).

Housing policy over the last 50 years has been structured around a politically initiated ideology of home ownership as normal and beneficial, and public housing as inferior. As an extension of the extensive financial and political support it receives, private ownership has also come to epitomise all that is embodied within ideological constructs of community; as being inherently good (Gurney, 1999; Kemeny, 1983, 1995; Peel, 1995).

Public housing, community, and the ideal of social mix

Public housing has been constructed as inferior and abnormal, especially that housing in large-scale housing estates. In recent years large-scale estates have been criticised on the basis of their concentration of economically disadvantaged residents (Reay \& Lucey, 2000; Randolph \& Judd, 2000; Haworth \& Manzi, 1999; Atkinson \& Kintrea, 2001), which in turn leads to a perceive lack of community (Foster, 1997; Peel, 1995). As a result community and neighbourhood are increasingly positioned as 
entities with the ability to alter many of the problems that are present in public housing estates (Bisset et al, 1994; Darcy, 1999; Evans, 1998; Marsh \& Mullins, 1998; Taylor, 1998; Franklin, 2000).

In an attempt to curtail many of the perceived problems associated with public housing tenancies, community development has become one of the main objectives of the New South Wales Department of Housing (NSWDoH) (Gallard, 1999). Community development (as used by the NSWDoH) is an ambiguous, ill-defined concept that lies at the centre of policies of social mix. According to the NSWDoH community development is an active process undertaken in an attempt to increase access to support services, and employment, to advance education and to enhance skills and interaction with the local community (Department of Housing, 2000a, 2000b).

Such an understanding of community development has two key components. First, through neighbourhood location, increased levels of service provision are argued to be secured. It is believed the development of areas of social mix will provide public tenants with greater access to services and facilities, as compared to those residing in large, poorly served estates. Second, increased 'community', which is believed to be most easily established by the placement of public tenants in communities containing, and preferably dominated by, private owners.

Policies of social mix are overt attempts to remedy problems associated with social exclusion in particular. They attempt to confront the two main housing related issues as identified by Somerville (1998): exclusion from labour markets and services; and the denial of social citizenship status, which can lead to stigmatisation, repressive or oppressive legislation and law enforcement, and forms of institutional discrimination. The NSWDoH, along with other state housing authorities in Australia 
and internationally, believe social inclusion is best promoted through the housing of public tenants within areas of private ownership (see Arthurson, 2002; Peel, 1995; Atkinson \& Kintrea, 2000; Galster \& Zobel, 1998; Marsh \& Mullins, 1998). Policies of social mix are based on in-built assumptions that the development of places that contain both owner-occupiers (the ideal) and public rental tenants (the 'other') can provide a world of jobs, education and stable family life to renters who would otherwise be socially excluded (Atkinson \& Kintrea, 2000; Evans, 1998; Galster \& Zobel, 1998).

\section{Belmont: a site of synthesis}

The empiric for this study is the suburb of Belmont, located within the boundaries of Lake Macquarie City Council, 19km south of Newcastle, NSW. Belmont grew from a small village in 1933 to one of the major residential and commercial centres of Lake Macquarie by the mid-1970s (LMCC, 1986). Public housing was first established in Belmont in 1949; however, the majority of public dwellings were developed between 1978 and 1982. Since this time the construction of public housing has continued, albeit in much smaller numbers. Currently there are 459 NSWDoH properties situated in Belmont, which accounts for 8 per cent of dwellings in the area. Importantly, the majority of NSWDoH properties are located in three concentrated areas, dominated by medium density developments and cul de sacs, which increasing the ratio on the smaller scale.

Belmont is well serviced by local shops, clubs and educational facilities. These facilities play an important part in the lives of local residents, as will be explored in later sections. Belmont was commonly considered by the NSWDoH employees who 
were interviewed to be close to the ideal size and composition of mixed tenancy areas. As such, it provides an appropriate case study for research on social mix.

\section{A methodology for examining the complex}

Data collection for this research involved the distribution of questionnaires to residents of Belmont (both private owners and public tenants ${ }^{1}$ ), and interviews of residents and key informants from the NSWDoH. A total of 480 questionnaires were distributed systematically to the residents within a 1 kilometre radius of public housing concentrations in an attempt to focus on the 'mixed' nature of Belmont. Sixty-eight questionnaires were returned for analysis, a response rate of $14.2 \%$. Although this is generally considered to be an inadequate response rate for most questionnaires (Babbie, 1998), it is consistent with response rates from other surveys conducted with public tenants (see Atkinson \& Kintrea, 2000), and slightly higher than that expected by NSWDoH housing managers: 'There's always someone studying them. I think if you get 5 to 10 per cent you'll be lucky' (NSWDoH Interview 5).

Semi-structured interviews were conducted with local residents, who volunteered in the questionnaire to further participation in the research. Minichiello et al (1995) argues that interviewing is a subtle way of gaining access to the meanings and interpretations that individuals give to their lives and the events within them. The use of in-depth interviews with residents within housing studies has been identified as one of the most productive methodologies for identifying relationships (Foster, 1997; Martin, 1987). In total 12 interviews of 1 hour in length were conducted with local residents. 
Interviews were also conducted with employees of the NSWDoH who were directly involved with the management of the Belmont area. The interviewing of NSWDoH employees allowed in-depth access to the often conflicting and shifting strategic logics and historical contingencies that underlie processes within the Department (Schoenberger, 1991). The in-depth interviewing of housing managers provided an insight into ideological concepts, such as community, which are implicit in the management of public tenants, though which are difficult to identify or analyse through written policy material.

\section{Perceptions of housing managers}

Housing managers are those employees of public housing authorities who implement housing policies and manage stock and tenants (Atkinson \& Kintrea, 2000). The current allocation policy of the NSWDoH gives no consideration to the match between tenant needs and the facilities offered by a location and revolves around the simple notion that 'if you come to the top of the list today, we will marry it up with the next vacancy. It could be in Windale, it could be in Charlestown, it could be in Belmont, it could be in Swansea' (NSWDoH Interview 5). Managers are unable to place the majority of tenants intentionally due to their social, cultural, or economic positions (age and disability are taken into account). Thus social mix, in terms of both community assimilation and access to services, may work to varying degrees depending on the accidental compatibility of a tenant's social attributes and the characteristic of the area in which they are placed.

Increasingly housing managers are required to play a role in the creation of more positive communities (Franklin, 2000). The NSWDoH (like other housing authorities) is increasingly driven by criteria such as value for money, efficiency, 
effectiveness, accountability, performance targets and benchmarking (Franklin, 2000), and as a result, projects and areas are prioritised in an attempt to allocate these scarce resources efficiently. As a result, the majority of time and financial resources are directed to large estate developments while other areas, such as Belmont, are effectively left to their own devices.

NSWDoH housing managers see Belmont as a locality where a strong community already exists, allowing tenants to 'escape within the community' (NSWDoH Interview 1). It is believed the community has the ability to resolve problems related to public housing residency (such as unemployment and lack of pride in one’s property) (Damer, 2000), or as one housing officer put it:

Eventually public housing people will be intermingled with the rest of society ... It's a good thing because the set of values that people have got, and the set of values of the neighbourhood is imposed upon these people whether they like it or not. They can see how they are expected to act (NSWDoH Interview 4)

This quotation suggests an underlying belief that public housing residents are normally situated outside the community, and that it is only with their inclusion into a community dominated by owner-occupiers that this exclusion can be overcome. One interviewee stated 'it's important that we put people where they are going to be readily accepted into the community’ (NSWDoH Interview 5). However, the fact that they have to be accepted implies a belief that public tenants are unable to develop their own communities, and if communities based on public housing residence were developed they would be viewed as inferior to those dominated by owners. It is the 
attributes of owners that are seen as positive and influential in the transformation of public housing tenants. However, the success of this community integration (or assimilation) strategy must be questioned, through examining the opinions and experiences of the residents.

\section{Residents’ opinions of community in Belmont}

Following on from housing managers' perceptions of community in Belmont, this section explores the success of community functions of social mix by looking at whether or not Belmont residents identify a community in their area, and how strongly they feel connected to that community.

\begin{tabular}{|c|c|c|c|c|}
\hline & \multicolumn{2}{|c|}{ Private Owners (\%) } & \multicolumn{2}{|c|}{ Public Tenants (\%) } \\
\hline & Yes & No & Yes & No \\
\hline Is there a community in Belmont? & 85.5 & 11.5 & 68.0 & 32.0 \\
\hline Is tenure important in community & & & & \\
\hline formation? & 69.6 & 30.4 & 78.3 & 22.7 \\
\hline
\end{tabular}

Table I Presence of Community and Importance of Tenure in Belmont

As shown in Table I, the majority of residents believed there was a community in the Belmont area, with $88.5 \%$ of owners and $68.0 \%$ of public housing tenants identifying a community, and interviews confirming 'It's a good community' (Owner Questionnaire 1) and 'It has a village community feeling' (Owner Interview 6). Such responses would suggest initially that policies of social mix through co-habitation are successful, however the situation is considerably more complex. Although $68 \%$ of 
public tenants did identify a community in Belmont, this is not to say they identify themselves as members of this community.

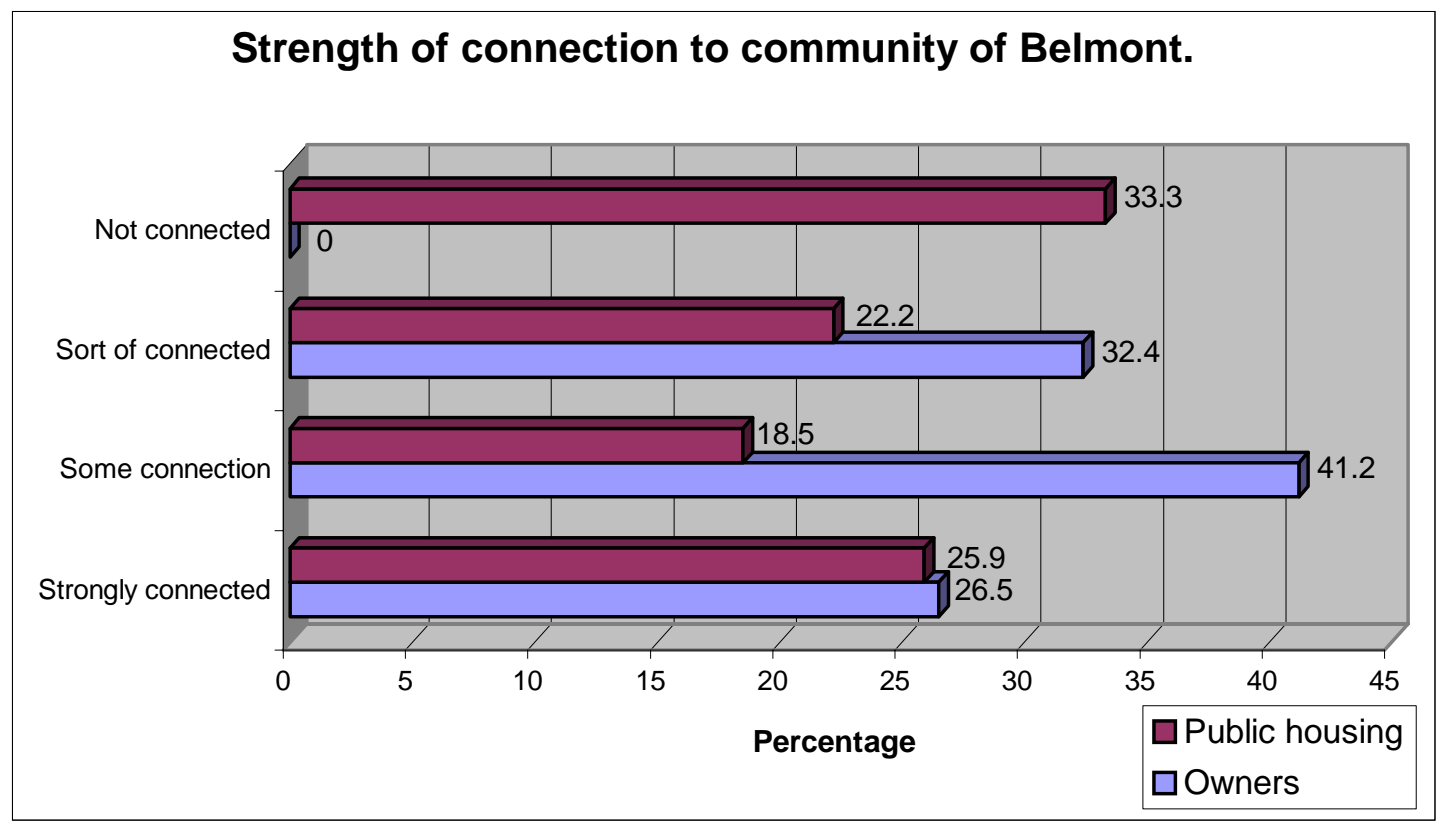

Figure 2 Strength of connection to community of Belmont

Figure 2 demonstrates how strongly residents feel attached to the community of Belmont. Significant differences between tenures are clearly visible. Most striking is the fact that $33.3 \%$ of public housing tenants who believed there was a community in Belmont considered themselves not to be connected to this community. This has important implications for policies of social mix, as clearly a significant proportion of public tenants feel they are not actively accepted into developed communities.

The majority of residents see tenure as a major factor contributing to community membership. Table I highlights that both private owners and public tenants, with $69.9 \%$ and $78.3 \%$ respectively, identify tenure as an important feature in community formation. The fact is that, despite the hopes of the NSWDoH, public housing dwellings in social mix neighbourhoods are easily identified, which results in private home owners identifying them as different and excluding them from their 
communities. Such findings are supported by a number of studies conducted by Marsh \& Mullins (1998), Somerville (1998), and Galster \& Zobel (1998) all of whom identify tenure as a major contributor to both local and broader scales of social exclusion. This exclusion will be discussed in the following section; however, it is important to note that a significant proportion of public housing tenants do consider themselves to be a member of a community. However, it is a community significantly different to that pursued by policies of social mix.

Many public tenants believed themselves to be a member of a community based solely on public housing tenancy. Residents identified these communities as playing a significant role in improving their lives and reducing many of the social exclusion problems associated with public tenancy:

I've got a never-ending supply of people in this complex who are poverty stricken as I am myself. I mean I gave every set of units, everyone, every unit that had kids I gave them a watermelon, and then I gave them to anyone who wanted them. I used to every fortnight put together maybe 2 or 3 tomatoes and apples, a lettuce and a cucumber, and whatever, and the ones in the complex who I knew had children and kids that were struggling like we were I used to send over little bundles of stuff (Public Housing Interview 5)

Such responses illustrate that there are indeed a communities of public housing tenants in the Belmont area; however, they are generally small-scale communities based on medium density complexes, or cul de sacs dominated by public housing. The formation of such community is based on support and friendship, under sometimes extremely difficult conditions (Peel, 1995; Taylor, 1998). Such findings 
contradict, to some extent, the belief of the NSWDoH which identified the integration of public tenants into a community dominated by owners as having the ability to alter these problems. Such disadvantages are often confronted and dealt with better by public housing residents who are in the same or similar situations. These findings are consistent with Young's (1999) work on residential segregation and citizenship based on race. Thus, it is conceivable that mixed tenancy areas need a certain level of public housing for support groups and communities to form and be sustained. Although these communities are based solely on public housing residence, and not a result of tenurial integration, as desired by the NSWDoH, they are as, if not more, important for the success of social mix areas.

Thus, Belmont does not constitute a single homogeneous community but a number of communities based on a myriad of social, economic and cultural criteria. Many residents, both those in private ownership and public housing, suggested that tenure separated and distinguished communities: 'I think most people in Belmont who are community minded would feel as though there are two sorts of Belmont' (Owner Interview 1); and 'I think the area has got two communities. It's not hard to pick who comes from public housing ... people tend to stay away from them' (Public Housing Interview 1). This identification of distinct communities has the ability to distinguish and differentiate public tenants and expose them to possible forces of exclusion and oppression.

\section{Public housing as the other and the process of oppression.}

Young (1990b) argues that the ideal of community denies and represses social difference and that polity cannot be thought of as a unity in which all participants share a common experience and common values. The ideal of community therefore 
can produce and reinforce segregation and exclusion within localities (Young, 1990a; Taylor, 1998; Somerville, 1998; Forrest \& Kearns, 2001; Buck, 2001). Social groups, in this case housing tenures, are seen as homogeneous. It is important to note here that process of differentiation and othering as identified by Young (1990b) and Cresswell (1996) results in the identification of public housing tenants as subordinate and different from dominant place identities, those of private owners, and ignore internal differences between tenants. Duncan (1993) argues that the development of simple binary opposites simplifies complex issues. Within this study the simple identification of the "us" and the "them" was common, with very few residents identifying internal complexity and difference. Nevertheless, the ideology of simple binary opposites which dominates discussion of public housing in Belmont has important implications for housing policy.

In accordance with mainstream ideology, private homeowners in Belmont are constructed by owners as inherently good. Owners were thought to provide better neighbours and thus the basis of a better community: 'It's better to associate with people who own their own home, they know how to act' (Owner Interview 2); 'A community which is dominated by private owners is better for the area, as it provides a better environment' (Owner Questionnaire 2); and 'I think you'll find that most owners hang around with other owners, they understand each other better' (Owner Interview 6).

In contrast public housing is seen as unnatural as it is believed to harbour all the undesirable features which the privileging of home ownership casts as inferior, undesirable and unwanted (Gurney, 1999; Evans, 1998; Taylor, 1998; Somerville, 1998). Public housing tenants feel they are rendered as different and inferior, stressing; 'Because I'm in public housing I'm not treated as equal and I'm not part of 
their community' (Public Housing Interview 5) and 'Despite the fact that I'm employed and pay up to $\$ 140$ per week rent ${ }^{2}$, I'm still looked down upon. Most of them want nothing to do with me. I'm less than what they are' (Public Housing Interview 6).

A clear association between social problems and public housing tenants was identified by owners: 'Crime’s always a possibility to me. Um, we are just a few streets away from where those (public housing) groups are’ (Owner Interview 4); 'In this area near public housing, vandalism, crime and drugs are far more prevalent' (Owner Interview 5); and 'They (public housing tenants) cause a lot of strife in the area, and it's known that they are involved in crime and drugs' (Owner Interview 1). The identification of public housing as the cause of the majority of the area's social problems has a number of implications. Firstly, it allows for public housing tenants to be positioned as other and inferior to owners, and secondly, the perceived absence of such problems from owner areas further perpetuates the ideology of community as appropriated by NSWDoH housing managers.

Peel (1995) in his study of Elizabeth identified that among residents who defined and grouped themselves as superior, a priority was to avoid mixing with those who they considered different. The identification of public tenants as embodying much of the socially unacceptable behaviour in Belmont allows owners to identify them as other. The association of deviant behaviour with public tenants by private owners, in their opinion, justifies segregation and their identification as other. In Belmont many owners commented that they actively stayed away from areas of public housing: 'There's been a lot of trouble in those commission places several streets away, I'm glad I'm not close to them...You just have to keep them at arms length' (Owner Interview 3) and ‘I walk almost every morning, but I don’t walk up near them 
(public housing). I'm a bit concerned for my personal safety' (Owner Interview 2). Whether public housing tenants are part of a single community which dominates Belmont, or form a community of their own, in the eyes of private owners the development and presence of public housing is seen to be 'a bit sad, because it does detract from the overall good points of the area' (Owner Interview 3).

Many public housing tenants in Belmont actively experience the process of othering and, in some cases oppression. Many public residents in Belmont pointed out that they are treated as different simply because of where they live:

I am in public housing and I'm not treated as an equal in either the community or my work place (Public Housing Interview 1)

I'm in the minority group. In Belmont there are the 'I ams' and the 'you're nots’ (Public Housing Questionnaire 1)

Public housing tenants are looked down on and treated as second class citizens (Public Housing Interview 5).

It is clear that, in contrast to the desires of the NSWDoH, public tenants actively experience oppression and stigmatisation. Ironically, it is these very forces of oppression and stigmatisation which play a significant role in the formulation of community based on public tenancy. Significantly though, in terms of areas of social mix, unlike with large estate developments, this oppression and differentiation is more prevalent at a smaller scale of social interaction (Vinson, 1996; Taylor, 1998; Randolph \& Judd, 2000). Instead of entire suburbs being stigmatised, in areas of 
social mix such as Belmont, this stigmatisation occurs more readily on an individual basis.

\section{The physical relation to place and the functions of neighbourhood}

This section principally explores the extent to which policies of social mix have achieved their physical goals in Belmont. The physical infrastructure of a location plays an important role in the day to day lives of local residents. In recent years there has been considerable academic writing concerned with the lack of facilities and services within or near public housing estates (Taylor, 1998; Randolph \& Judd, 2000, 1999; Vinson, 1996). It is these and similar reports which have paved the ideological path for policies of social mix and the belief that these areas provide adequate service infrastructure to public tenants. Such an assertion is supported by public tenants in Belmont who believe that 'the area needs home owners and private rental, as the council would never do anything if the area were all public housing. There would be nothing for us’ (Public Housing Questionnaire 2).

Public housing tenants use local facilities, such as shops and sporting fields, more frequently than private owners in the area, with $41.6 \%$ of public tenants using facilities at least weekly compared to only $26.2 \%$ of private owners. Such findings suggest that public tenants rely more heavily on facilities in the immediate area, with residents identifying that 'I do 99\% of my shopping here' (Public Housing Interview 3) and 'Everything I need is just down the street' (Public Housing Questionnaire 3). Importantly, however, this does not of itself indicate that they are part of a community, as the use of local facilities does not in itself guarantee social interaction or community formation. Such results do indicate nonetheless that policies of social mix, at least in terms of service provision, are having some success. 
Transport is of major importance in relation to access to internal and external neighbourhood facilities. Although a significant number of public residents own motor vehicles, the reliance of many public tenants on public transport was stressed, "I rely on public transport to get everywhere. That makes it really difficult at times" (Public housing Interview 6). These findings are consistent with Atkinson \& Kintrea's (2000) study of mixed tenancy areas in Britain which identified transport as a key issue in shaping people's daily lives. This reliance on public transport means public tenants find it just as difficult to utilise facilities located outside a mixed tenancy neighbourhood as they would those outside a housing estate, as illustrated by responses such as:

If I want to go somewhere, like to TAFE that is in Hamilton, or take my son to the doctor, its almost impossible. First we have to catch as bus from here to Charlestown Square. From there we have to catch a bus into town, and finally a bus from town to Hamilton or wherever. And some of the time my son's ticket runs out so I have to buy 2 tickets instead of one. And when I've done whatever I have to do, it's the same thing to get back home (Public Housing Interview 5).

It is important to note public housing tenants' reliance on local facilities has some important implications for community formation. Firstly, the strong association with local facilities and the related difficulty using other facilities, is a result of material conditions. Public tenants rely on local facilities, as they are easier to access than other facilities. This is often the result of economic circumstances, 'I just can't afford a car' (Public Housing Interview 5). Secondly, the reliance of public housing 
tenants on local facilities may in fact identify them as disadvantaged. As Taylor (1998) argued, 'in a society where people are supposed to have choice, residents are further excluded by their 'dependency' on local service’ (p.827). This reliance on local facilities may be one way in which private owners within Belmont identify public tenants as inferior and other: 'It's good for them (public housing tenants) to be here because they can go down to the shops when then need something. That's something they can't do in Windale. But we don't go down there. We like the shops at Mt. Hutton better' (Owner Interview 6).

In contrast to the difficulties presented in previous sections, it can be seen that in terms of increased access to services, policies of social mix have been partly accomplished in Belmont, with public tenants having access to established facilities within their own neighbourhood. However, like public tenants in large estates, they still experience difficulty in gaining access to important facilities which are located away from Belmont.

\section{Conclusion}

The ideology of community has come to represent the ideal solution to the myriad of problems now confronting public housing. As such it is increasingly gaining prevalence as a policy goal in housing departments. With an ever-increasing number of studies criticising the development, management and outcomes of large public housing estates, policies of social mix are rapidly moving to the ideological forefront of policy development. This paper has explored the ideological beliefs which form the foundations of both notions of community and notions of social mix embedded within the management and policy arenas of the NSWDoH. 
The research suggests that the ideology of community which influences policies of community development and social mix is far from perfect. In areas of social mix, public tenants are not readily accepted into communities dominated by private owners. They are actively constructed as different and experience forces of oppression, stigmatisation and exclusion. However; it is equally important to note than in terms of service provision, areas of social mix are seen by residents as better equipped than public housing estate developments.

It is the scale of these processes which is important. By developing smaller scale areas of social mix, the NSWDoH is removing much of the stigmatisation associated with large-scale estate developments. Public housing tenants in Belmont did not identify themselves as being stigmatised because they lived in Belmont. This would not be the case if they lived in estate development such as Mt. Druitt, Green Valley (Dowling, 1999), Booragul, or Windale. Thus the Department considers Belmont, and indeed policies of social mix more broadly, to be a success. However, the movement of experiences of oppression to a smaller scale does not indicate success of community. Within the neighbourhood, residents are identified as different because they live in small pockets of public housing which are quite easily identified, despite housing managers’ aspirations. These residents are individually identified and “kept at arms length” within their own suburb.

Policies of social mix are not the quick fix solutions to the problems associated with public housing tenants, at least in the Belmont area. This research has identified the inadequacies of ideological constructions of community, and the belief that assimilation of public tenants into owner-occupied communities occurs simultaneously and has a wholly positive influence. However, it also demonstrates the important role neighbourhood plays in service provision. Social mix has significant 
and complex implications for the social worlds of residents, both negative and positive. Thus, it is clear future research in other areas of social mix and continued policy development is needed.

\section{ACKNOWLEDGMENTS}

This paper results from honours research conducted by Kristian Ruming. The research was facilitated by provision of an Honours scholarship as part of an ARC Linkage project between the Centre for Urban and Regional Studies, The University of Newcastle and the NSW Department of Housing Hunter Region Head Office. The authors would like to thank the NSW Department of Housing for their support of the project. Thanks are also due to the residetns' of Belmont who volunteered their time to participate in the research.

\section{NOTES}

1 Due to an extremely low response rate from private renters, this research focuses solely on public housing tenants and private owners.

$2 \$ 140$ per week represents market rent for this property in the Newcastle property market.

\section{REFERENCES}

Altman, I. and Wandersman, A., 1987: Introduction. In Altman, I. and Wandersman, A. (eds) Neighbourhood and Community Environments, Plenum Press, New York.

Amin, A. and Thrift, N., 2002: Cities: Reimaging the Urban. Blackwell, New York. Anderson, B., 1991: Imagined Communities. Verso, London. 
Arthurson, K., 2002: Creating Inclusive Communities through Balancing Social Mix: A Critical Relationship or Tenuous Link?. Urban Policy and Research 20, 245261.

Atkinson, R. and Kintrea, K., 2000: Owner-occupation, social mix and neighborhood impacts. Policy and Politics 28, 93-108.

Atkinson, R. and Kintrea, K., 2001: Disentangling Area Effects: evidence from deprived and non-deprived neighbourhoods. Urban Studies 38, 2277-2298.

Babbie, E., 1998: The Practice of Social Research. Wadworth Publishing Company, Melbourne.

Bisset, H., Dalton, T. and Lawson, J., 1994: Community Housing in Australia: Issues and Future Directions. Australian Housing and Urban Research Institute, Melbourne.

Buck, N., 2001: Identifying Neighbourhood Effects on Social Exclusion. Urban Studies 38, 2251-2275.

Caulfield, J., 2000: Public Housing and Intergovernmental Reform in the 1990s. Australian Journal of Political Science 35, 99-110.

Cresswell, T., 1996: In Place/Out of Place: geography, ideology and transgression. University of Minnesota Press, Minneonapolis.

Damer, S., 2000: Engineers of the human Machine: The Social Practice of Council Housing Management in Glasgow, 1985-1939. Urban Studies 37, 2007-2026.

Darcy, M., 1999: The Discourse of 'Community’ and the Reinvention of Social Housing Policy in Australia. Urban Studies 36, 13-26.

Dowling, R., 1999: 'Symbolisms of Class and Suburbia in Mount Druitt, Australia'. Unpublished paper. 
Duncan, J. 1993: Sites of Representation: Place, time and discourse of the Other. In Duncan, J. and Ley, D. (eds) place/culture/representation. Routledge, New York.

Dwyer, C., 1999: Contradictions of community: questions of identity for young British Muslim women. Environment and Planning A 31, 53-68.

Evans, R., 1998: Tackling Deprivation of Social Housing Estate in England: An Assessment of the Housing Plus Approach. Housing Studies 13, 713-726.

Forrest, R. and Kearns, A., 1999: Joined-up places?: Social cohesion and neighbourhood regeneration. Joseph Rowntree Foundation, Laterthorpe.

Foster, J., 1997: Challenging Perceptions: Community and neighbourliness in a difficult-to-let-estate. In Jewson, N. and McGragor, S. (eds) Transforming Cities. Routledge, New York.

Franklin, B.J., 2000: Demands, Expectations and Responses: The Shaping of Housing Management. Housing Studies 15, 907-927.

Gallard, A., 1999: Civic Re-engagement-Partnerships with the Community. Paper presented to the National Housing Conference, Canberra.

Galster, G. and Zobel, A., 1998: Will Dispersed Housing Programmes Reduce Social Problems in the US?. Housing Studies 13, 605-622.

Galster, G., 2001: On the Nature of Neighbourhood. Urban Studies 38, 2111-2124.

Gurney, C., 1999: Pride and Prejudice: Discourse of Normalisation on Public and Private Accounts of Home Ownership. Housing Studies 14, 163-183.

Haworth, A. and Manzi, T., 1999: Managing the Underclass: Interpreting the Moral Discourse of Housing Management. Urban Studies 36, 153-165.

Jacobs, J.M. and Fincher, R., 1998: Cities of Difference. Guilford Press, New York. 
Jewkes, R. and Murcott, A., 1998: Community Representatives: Representing the Community. Social Science and Medicine 46, 843-858.

Kearns, A. and Parkinson, M., 2001: The Significance of Neighbourhood. Urban Studies 38, 2103-2110.

Kemeny, J., 1981: The Myth of Home-Ownership: Private versus public choices in housing tenure. Routledge, London.

Kemeny, J., 1983: The Great Australian Nightmare: a critique of the home-ownership ideology. Georgian House, Melbourne.

Kemeny, J., 1995: From public housing to the social market: Rental policy strategies in comparative perspective. Routledge, London.

Lake Macquarie City Council, 1986: Lake Macquarie Community Profile, 1986

March, A. and Mullins, D., 1998: The Social Exclusion Perspective and Housing Studies: Origins, Applications and Limitations. Housing Studies 13, 749-759.

Martin, J.I., 1987: Suburbia: Community and Network. In Encel, S. and Berry, M. (eds) Selected Readings in Australian Society: An Anthropology. Longman Cheshire, New York.

Massey, D., 1991: The political place of locality studies. Environment and Planning A 23, 267-281.

Minichiello, V., Aroni, R., Timewell, E. and Alexander, L., 1995: In-Depth Interviewing: Principles, Techniques, Analysis. Longman, Sydney.

New South Wales Department of Housing, 2000a: Corporate Plan 2000-2003.

New South Wales Department of Housing, 2000b: Healthy Housing Communities.

Paris, C., 1993: Housing Australia. MacMillan Education, Melbourne.

Peel, M., 1995: Good Times, Hard Times: The past and present in Elizabeth. Melbourne Uni Press, Melbourne. 
Plant, R., 1974: Community and Ideology: an essay in applied social philosophy. Routledge \& Keyan Paul, London.

Randolph, B. and Judd, B., 2000: Community Renewal and Large Public housing Estates. Urban Policy and Research 18, 91-104.

Reay, D. and Lacey, H., 2000: 'I don't really like it here but I don't want to be anywhere else': children and inner city council estates. Antipode 34, 410-428.

Rivlin, L.G., 1987: The Neighborhood, Personal Identity, and Group Affiliations. In Altman, I. and Wandersman, A. (eds) Neighborhood and Community Environments. Plenum Press, New York.

Richards, L., 1990: nobody's home: Dreams and Realities in a New Suburb. Oxford University Press, Melbourne.

Rodriguez, J.A., 1998: Local history, public art and community in an urbanising suburb. Ecumene 5, 220-236.

Schoenberger, E., 1991: The corporate interview as a research method in economic geography. Professional Geographer 43, 582-599.

Sexton, R., 1995: Parallel Utopias. Chronicle Books, San Francisco.

Silk, J., 1999: The dynamics of community, place, and identity. Environment and Planning A 31, 5-17.

Somerville, P., 1998: Explanations of Social Exclusion: Where Does Housing Fit in?. Housing Studies 13, 761-780.

Smith, D.M., 1999: Geography, community, and morality. Environment and Planning A 31,19-35.

Studdent, D., 1999: Bondi, Baywatch and the Battle for Community. Arena Magazine August, 28-33. 
Taylor, M., 1998: Combating the Social Exclusion of Housing Estates. Housing Studies 13, 819-832.

Vinson, T., 1996: Waterloo Estate Study. School of Social Work, University of New South Wales, Sydney.

Wild, R.A., 1981: Australian Community Studies and Beyond. George, Allen \& Unwin, Sydney.

Williams, R., 1976: Keywords: a survey of Culture and Society. Croom Helm, London.

Yates, J. and Vipond, J., 1991: Housing and Urban Inequalities. In Social Justice Collective (ed.) Inequality in Australia. Heineman, Melbourne.

Yates, J. and Wulff, M., 2000: W(h)ither Low Cost Private Rental Housing?. Urban Policy and Research 18, 45-64.

Young, I.M., 1990a: The Ideal of Community and the Politics of Difference. In Nicholson, L.J. (ed.) Feminism/Postmodernism. Routledge, New York.

Young, I.M., 1990b: Justice and the Politics of Difference. Princeton Uni Press, Princeton, New Jersey.

Young, I.M., 1999: Residential Segregation and Differential Citizenship. Citizenship Studies 2, 237-252. 


\section{List of figures}

Figure 1 Normative assumptions of community.

Figure 2 Strength of connection to community of Belmont 


\begin{tabular}{|c|c|}
\hline Small-scale & $\begin{array}{c}\text { Common values } \\
\text { Cocal }\end{array}$ \\
Togetherness & Common experiences \\
Belonging & Working towards common goals \\
Cohesion & Symmetry \\
Mutually sympathetic & \\
$\square$ & (Mutual) Support \\
\hline
\end{tabular}

Figure 1 - Normative assumptions of community.

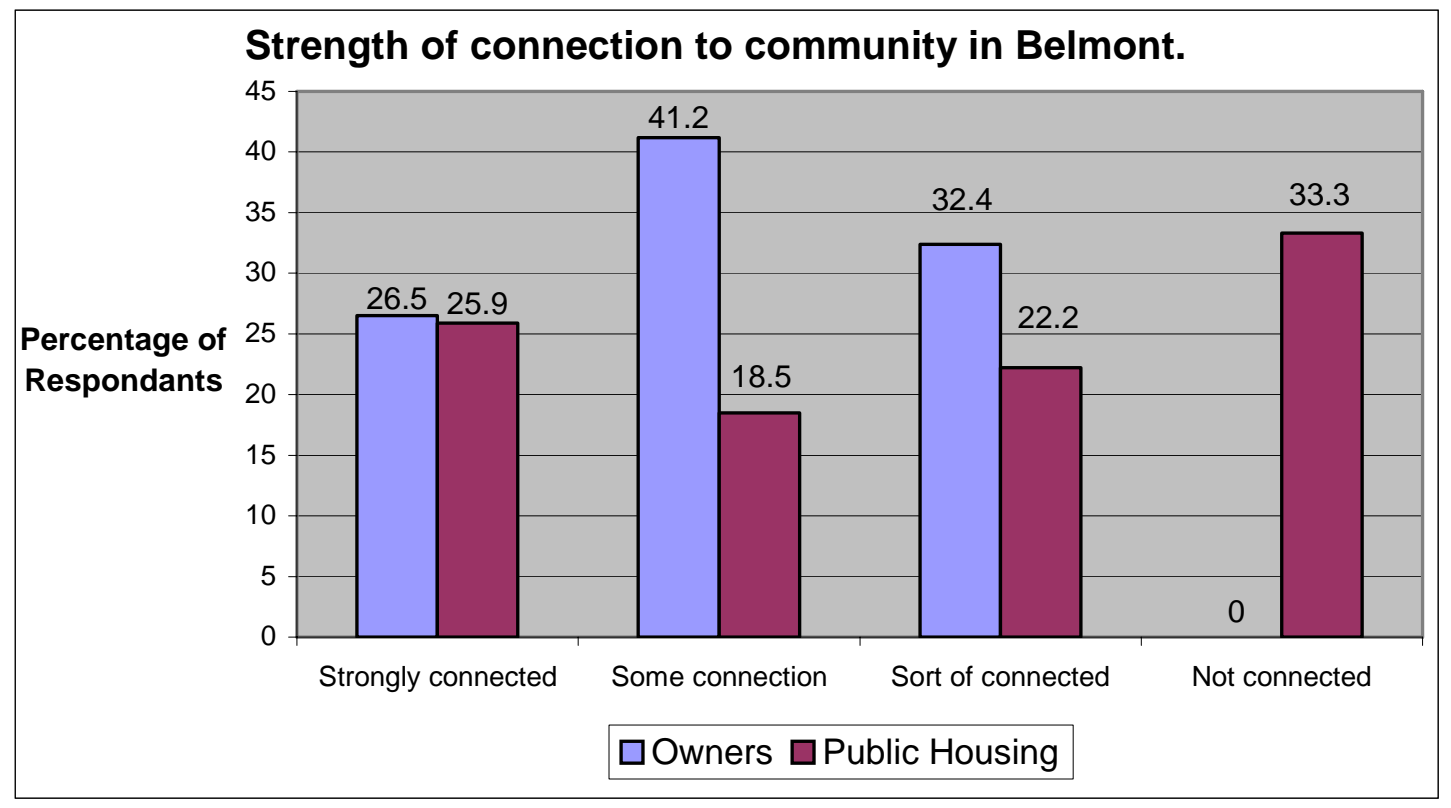

Figure 2 Strength of connection to community of Belmont 


\section{List of Tables}

Table I Presence of Community and Importance of Tenure in Belmont

Table I Presence of Community and Importance of Tenure in Belmont

\begin{tabular}{|lccccc|}
\hline & \multicolumn{2}{c}{ Private Owners (\%) } & & \multicolumn{2}{c|}{ Public Tenants (\%) } \\
\cline { 2 - 3 } \cline { 5 - 6 } & Yes & No & & Yes & No \\
\hline Is there a community in Belmont? & 88.5 & 11.5 & & 68.0 & 32.0 \\
Is tenure important in community & & & & & \\
formation? & 69.6 & 30.4 & & 78.3 & 22.7 \\
\hline
\end{tabular}

